Copyright (C) 2000 by The Resilience Alliance

The following is the established format for referencing this article:

Gadgil, M. 2000. Comments on "Genetically modified crops: risks and promise" by Gordon Conway. Conservation Ecology 4(1): 9. [online] URL: http://www.consecol.org/vol4/iss1/art9

\title{
Commentary
}

\section{Comments on "Genetically Modified Crops: Risks and Promise" by Gordon Conway}

\section{Madhav Gadgil}

\section{Indian Institute of Science}

- Responses to this Article

- Literature Cited

KEY WORDS: citizen science, exclusion, global development, green revolution, new culture, plant biotechnology, poverty, public participation.

I find myself in full sympathy with Gordon Conway's analysis and prescriptions (Conway 2000). I especially agree with his call for a new culture, with appropriate systems and ongoing institutional support, that provides careful monitoring, open reporting and transparency, and above all, a place for public participation about the impact of plant biotechnology on the environment, human health, and the viability and sustainability of the food system. We need not only the transnational corporations, such as Monsanto to which Conway's remarks were addressed, but also governments of the developed and the developing world, and the scientific establishment, to promote the emergence of such a new culture. 
Let me begin by recalling an incident that took place in 1982, when India was happy and relieved at having organized the first green revolution. I was then a member of a Government of India committee to advise on legislation and other measures to promote environmental protection. On behalf of this committee, I had spent over a month talking to fishers, herders, peasants, and rural artisans about their perceptions of India's environmental problems in many different parts of the country. One of the themes that recurred in these conversations was the perception, across the board, that the green revolution was depleting the fertility of India's agricultural soils. At a public meeting in Bangalore, presided over by a distinguished economist who had served two terms in the parliament and had been a Minister for Education, I shared this perception. I was berated for making ignorant statements on the basis of conversations with irresponsible villagers. In other words, I was faulted for attempting to initiate a public dialogue with the poor and the excluded on the processes of agricultural development - just what Conway is calling for.

As we approach the new millenium, fully half of India's nearly one billion people continue to remain poor and excluded. They belong to Dasmann's (1988) category of ecosystem people; people who continue to meet the bulk of their material requirements not from markets, but on the basis of gathering, fishing, or low-input cultivation and animal husbandry from their own immediate surroundings. These people have exceedingly limited access to goods and services generated through the organized economy (Gadgil and Guha 1995). Commercial profits that drive this economy arise, to a great degree, from tinkering, tampering with, and manipulating the natural world; e.g., replacing the natural restoration of fertility in slash-and-burn cultivation, or use of organic manure in low-input agriculture, with chemical fertilizers. If such practices are not sustainable in the long run, it merely opens up further commercial opportunities, for example, for new kinds of chemical fertilizers containing micronutrients, or for genetically engineered crops capable of growing in highly degraded soils. Thus, the economic drive is for more and more intense tinkering of nature, which unfortunately excludes the ecosystem people, half or more of the population of the entire developing world, leaving them impoverished.

If we accept, with Conway, the necessity of reversing this tendency of exclusion and impoverishment, we must develop ways of working not against, but with, nature; working not at the cost of, but to the benefit of these 
ecosystem people. We will inevitably continue to tinker with nature, but we should do so much more intelligently, bearing in mind, as Conway says, the precautionary principle. The secret of intelligent tinkering is to keep all of the parts, and it is here that a partnership with ecosystem people can be of much value. These people are part of the functioning of the local, complex ecosystems as they pursue their livelihoods; they have a better grasp than any outside experts of many of the relevant components (Gadgil et al. 1993). Of course, their experiential knowledge is rather limited in space, but for their specific localities, it is rich in detail. In particular, their historical observations include much understanding of the consequences of natural experiments in their own ecosystems. Given the difficulty of conducting careful, replicated experiments with these complex systems, such natural experiments are of much scientific value. These people are also engaged in practicing their own brand of adaptive management, adjusting their utilization patterns in light of experience (Gadgil et al. 1997). As their control of the local environment has weakened, they have lost both their understanding and capacity for adaptive management; nevertheless, these are of great potential value (Hannah and Munasinghe 1995).

There is thus a very strong case for developing a new culture, with new institutional structures, to build bridges with the poor and excluded. Involving them as equal partners in development efforts would confer dignity on them. This needs strong support from the governments of the developing countries to devolve power down to the lowest level; a tendency that is gaining strength in India and elsewhere as democracy strikes roots. Governments of developed countries and the transnational corporations that are a major influence on these governments must also support such empowerment of local communities. The scientific establishment, too, must develop new ways of bringing together the experiential knowledge of the people with the formal body of scientific knowledge. It needs to create new systems of recognition and rewards to foster such efforts. It needs to nourish what has been termed "citizen science."

\section{RESPONSES TO THIS ARTICLE}

Responses to this article are invited. If accepted for publication, your response will be hyperlinked to the article. To submit a comment, follow this link. To 
read comments already accepted, follow this link.

\section{LITERATURE CITED}

Conway, G. 2000. Genetically modified crops: risks and promise. Conservation Ecology 4(1): 2. [online] URL: http://www.consecol.org/vol4/iss 1/art2

Dasmann, R. F.1988. Towards a biology of consciousness. Pages 177-188 in D. Worster, editor. The ends of the Earth: Perspectives on modern environmental history. Cambridge University Press, Cambridge, UK.

Gadgil, M., F. Berkes, and C. Folke. 1993. Indigenous knowledge for biodiversity conservation. Ambio XXII(2-3):151-156.

Gadgil, M., and R. Guha. 1995. Ecology and equity: Use and abuse of nature in contemporary India. Routledge, London, UK.

Gadgil, M., N. S. Hemam, and B. M. Reddy. 1997. People, refugia and resilience. Pages 30-47 in C. Folke and F. Berkes, editors. Linking social and ecological systems. Cambridge University Press, Cambridge, UK.

Hannah, S., and M. Munasinghe, editors. 1995. Property rights in a social and ecological context. The Beijer International Institute of Ecological Economics and The World Bank, Washington, D.C., USA.

\footnotetext{
Address of Correspondent:

Madhav Gadgil

Centre for Ecological Sciences

Indian Institute of Science

Bangalore 560012 India

Phone: +++91 803601453,3600985

madhav@ces.iisc.ernet.in
} 